Colloquia Litteraria

UKSW

$2 / 2015$

BERNADETTA KUCZERA-CHACHULSKA

\title{
O POLSKIEJ POEZJI PO 1989 ROKU \\ (BRAKI I „NADDATKI”) - SZKIC KRYTYCZNOLITERACKI
}

Poezja niemal zawsze była sztuką. Nawet wówczas, kiedy myśl teoretyzująca niekoniecznie twórczość poetycką tam kwalifikowała; nawet wtedy, gdy - jak z dzisiejszej perspektywy mogłoby się wydawać - jedynie opowiadała jakąś historię, relacjonowała temat. Jej staranna, szczegółowo znormatywizowana forma stawała się przeźroczysta. Ostatnim tego typu, najbardziej widocznym zespołem norm były systemy wersyfikacyjne, zaczynające się kruszyć w XIX wieku. Dziesięciolecia wolnego wiersza, rozbite w krótkie wersy wypowiedzi Herberta, luźna, zadziwiająca strzępiastość Białoszewskiego, doprowadziły do sytuacji, w której poezją, w powszechnym mniemaniu, a także mniemaniu niektórych krytyków i literaturoznawców, może stać się wszystko, w dowolny niemal sposób zapisane. Na Miłosza patrzymy chwilami może nieufnie i niepewnie; mierzymy się z siłą zawartości jego przekazu, będącego rezultatem niezwykle sprawnego słowa, wychwytującego te sfery rzeczywistości, które rozpoznajemy jako egzystencjalnie, społecznie najważniejsze, ale nie potrafimy, nie umieliśmy do tej pory ich wyrazić; ale równie często nie możemy jeszcze nic z tym - co Miłosz zostawił - zrobić. Nie wiemy, jak tę ogromną wiedzę uzyskaną w obrębie sztuki słowa ulokować, co właściwie wynika z kształtu wierszy, które na mapie poezji XX wieku najbardziej korespondują z tradycyjnym językiem poezji. Gloryfikujemy ostatnie tomy Miłosza na zasadzie analogicznej do hołubienia 
liryków lozańskich Mickiewicza; wiersze wielkiego poety - ale - co z nich i ich miejsca w naszej współczesności chcemy zrozumieć?

Obecne mniemania o poezji zdają się polaryzować; z jednej strony mamy na przykład brawurowy szkic Lidii Burskiej o poetach miasta ${ }^{2}$, waloryzujący pozytywnie współczesny amorfizm, dezintegrację, rozproszenie (a zatem to, co pozostaje w rażącej sprzeczności z odwieczną naturą poezji), z drugiej natomiast - odgórne narzucanie sobie przez poetów idei o charakterze społecznym, politycznym, rozświetlanych postawą poszukiwaczy wartości, moralno-ideowego, twardego gruntu w świecie uciekającym spod nóg. Jednych i drugich - wbrew polaryzacji-łączyczęsto niska świadomość tradycji języka artystycznego, języka, którym się posługują, co stanowi punkt wyjścia do porażki.

Zdaje się w czasach nam współczesnych obowiązywać dążenie do powielania zdań, formuł i wersów, oby było ich jak najwięcej; oby te kolejne sprawiały wrażenie elokwentnych, „intelektualnych”. A przecież wiadomo, że największa sprawność językowa i najwybitniejsza inteligencja nie gwarantują dobrej poezji, udanego wiersza, chociaż i jedna, i druga są niezbędne, by znakomita liryka mogła zaistnieć. To "coś więcej” bywa trudno uchwytne, mierzyli się z jego charakterem najwybitniejsi znawcy form lirycznych; nie miejsce tu, żeby wchodzić szczegółowo w tę problematykę teoretyczną.

Bywa często tak, może coraz częściej, zwłaszcza jeśli chodzi o konkursy poetyckie - okoliczności, w których trzeba dokonać jakiejkolwiek hierarchizacji poezji czy tak zwanej poezji - że bierze się pod uwagę zewnętrzny, „wizerunkowy” poziom dyskursu, budowanego przez kolejne zdania; właśnie: dyskursu, a przecież poezja dyskursem nie jest, nie może być. Dyskursywność jest zaprzeczeniem poezji (i nie chodzi tu o zewnętrzny, literalny kształt językowy, ale o wewnętrzną

1 Zob. Bernadetta Kuczera- Chachulska, Późne arcydzieła Miłosza, w: tejże, Z estetyki nieskończoności. Szkice o polskiej poezji (nie tylko) XX wieku, Warszawa 2012.

2 Lidia Burska, Miasto i poezja, w: Co dalej, literaturo? Jak zmienia się wspótcześnie pojęcie i sytuacja literatury, praca zbiorowa pod red. Aliny Brodzkiej-Wald, Hanny Gosk i Andrzeja Wernera, Warszawa 2008. 
naturę wypowiedzi). Im więcej sprawnie, czasami po mistrzowsku połączonych słów, tym lepsza jurorom wydaje się poezja. A poezja, poszczególny wiersz, wymagają osobnego miejsca w czasie, jak zatem wyłonić laureata konkursu spośród parudziesięciu, a częściej paruset propozycji? To na pewno nie jest dobre sito dla poezji, jeśli chodzi nam o tę autentyczną, która ma przetrwać.

Któryś z krytyków, członek komisji konkursowej dla najmłodszych pretendentów do bycia poetami, podzielił się ze mną ostatnio obserwacją, że ci młodzi aktualnie coraz lepiej piszą, że poziom ogólny startów poetyckich jest coraz lepszy. Przyglądałam się wielu takim wierszom, rzeczywiście sprawność werbalna znakomita - i chyba niewiele więcej.

Rilke, pamiętamy to niemal jak truizm, mówił w Maltem, że dobry wiersz można napisać dopiero po przeżyciu bardzo wielu lat, rzadko u początków indywidualnego życia. Wydaje się, że ten sąd w dalszym ciągu pozostaje trafny, koresponduje niepodważalnie $z$ naturą poezji, która nie jest, nie powinna być ani żonglerką intelektualną, ani pokazem mody na najbardziej wymyślne sposoby negacji społecznej, kulturowej, kontestacją, ale też nie:

„notatnikiem lirycznym”, a więc opowiadaniem o uczuciach (lub zabarwionym uczuciowo świecie $[\ldots])^{3}$;

„Zwałką papki” [...] poezją robioną z poezji czy filozofii zastanej ${ }^{4}$;

eksperymentem, ponieważ ta [poezja] bywa w rezultacie zabawą w słowo ${ }^{5}$;

Poezja pierwotnie to możliwość ontyczna bytu ludzkiego, z realizacji której powstają poetyckie dzieła. Jeżeli jednak oprócz dzieł literackich istnieje „poezja” jako coś na równi z nim rzeczywistego, to może ona być jedynie sposobem istnienia jednostkowego człowieka. Die Poesie ist - die Seinsweise des Daseins, to jest jedyne poprawne określenie, które przed utworami poetyckim ujawnia istnienie twórcy i pozwala

3 Janusz Połomski, Poezja a filozofia, „Twórczość” 1969, nr 9, s. 70.

4 Tamże, s. 71.

5 Tamże. 
same utwory rozumieć jako rezultat pewnych określonych jego zachowań. Po grecku poezja [...] oznacza pewne zachowanie bytu ludzkiego, „tworzenie”; poezja jako poiesis to tworzenie w sensie powoływania do istnienia tego, co dotychczas nie istniało w mowie, wypowiadanie dotychczas niewypowiedzianego - określenie to zabrzmieć może jak banalny ogólnik, ale sens ma zgoła niebanalny, jeżeli, próbując go zrozumieć, odróżni się mowę od języka i słowo od terminów, tak jak odróżniali za Platonem Grecy [...]. Tak jak istnieje klasyczna koncepcja prawdy czy wolności, istnieje również klasyczna koncepcja poezji - ją wypowiada powyższe określenie. Warto je zachować. Pozwala ono oddzielić poezję od niepoezji, a więc od całej mnogości wierszy ruchu literackiego, oraz dojść do tego, co najbardziej własne u każdego autentycznego poety $^{6}$ [podkr. B.K.Ch.].

Na nic zdadzą się określenia: poezja metafizyczna, albo niemetafizyczna, kobieca albo męska, religijna albo niereligijna; poezja jest albo jej nie ma. Tak maksymalistycznie zarysowany problem sensu istnienia, miejsca i charakteru poezji wchodzi oczywiście w sferę problemów struktury języka ojczystego tego, kto pisze. Jak posługiwać się tymi strukturami? Na ile jest to możliwe, a na ile po prostu ważne, niezbędne? Jest to język, który w procesie swojego rozwoju wiele już odkrył, odsłonił w swoim historycznym trwaniu, ale chcąc odkrywać dalej, musi własną tradycję przekroczyć. Żeby tradycję przekroczyć, trzeba najpierw ją znać, umieć się nią posługiwać, na jej bazie dokonywać „konstrukcji” wyższego rzędu. Paul Valéry powiedział kiedyś dość hiperbolicznie, że każdy poeta musi znać wszystkie rymy możliwe w jego ojczystym języku. Myślę, że niekoniecznie o rymy chodzi i niekoniecznie tak właśnie należałoby postawić problem; chodzi po prostu o to, że każdy piszący powinien dysponować czymś w rodzaju głębokiego doświadczenia możliwości obrazowych, asocjacyjnych, metaforycznych, jakie dokonały się w obrębie określonego języka. Wówczas poeta będzie mógł używać odpowiednio tej właśnie mowy, by iść dalej, a nie dreptać w miejscu, udając, że dokonuje przełomów.

\footnotetext{
6 Tamże, s. 72.
} 
Po tych wstępnych i bardzo niekompletnych ustaleniach, chciałabym przejść do $\mathrm{kilku}$ w y b a n y ch przykładó w. Powtórzę: nie interesuje mnie ruch literacki, a zatem konkursy, nagrody, medialne kreacje, ulubieńcy krytyki, która zgubiła swoje narzędzia, liczba wydanych tomików i „odprawionych” wieczorów autorskich, zabiegi o rozgłos; interesuje mnie poezja.

Zacznę od tych autorów, których obecność w niepisanym kanonie chciałabym trochę „zminimalizować”, ograniczyć.

Adam Zagajewski; poeta dobrze wykształcony (znający tradycję, zadomowiony w kulturze), z pewną łatwością utrzymujący się na średnim, dość klasycznym poziomie. Na uwagę zasługuje może ten klasycyzm, łatwość przebywania poety na tematycznym piętrze wypracowanym nieco przez Miłosza, nieco przez innych poetów $\mathrm{XX}$ wieku, z wyraźnym oddechem na tradycję. Poeta publikujący dużo, mnożący liczbę tomów.

Biorę ostatni zbiór - Asymetrie, z 2014 roku (Wydawnictwo a5), otwieram przypadkowo na wierszu Noc, morze (s. 44):
W nocy morze jest ciemne, matowe
i mówi ochrypłym szeptem
w ten sposób poznajemy
jego wstydliwy sekret: ono świeci
odbitym blaskiem
W nocy jest biedne tak jak my wszyscy,
czarne, osierocone;
cierpliwie czeka na powrót słońca.

Nie wiem, co w tym wierszu pozwala na wyniesienie go ponad licealną wprawkę, nie rozumiem, jaka prawda została w nim odsłonięta. Zakładając wstępnie moją nieudolną percepcję, zwróćmy uwage na system epitetowo-metaforyczny wiersza: „morze ciemne i matowe”, „ochrypły szept”, „świecenie odbitym blaskiem”, i zdumiewająco mizerną analogię: „W nocy jest biedne tak jak my wszyscy, / czarne, osierocone".

Sposób łączenia poszczególnych figur, frazeologizmy wyjątkowo nie przekonują. Bywa tak w poezji, że niezborny język, siermiężny 
obraz coś usprawiedliwia, ale tutaj tego usprawiedliwienia (immanentnego i kontekstowego) nie umiem odnaleźć.

Otwieram tom na końcu; wiersz Nasze pótnocne miasta:

Nasze północne miasta drzemią na równinach

Ich mury, grube mury, wiedzą o nas wszystko

To są więzienia, na ogół dobroduszne

Idziemy pod potężnymi stropami

Wiatr bełkoce w konarach bezlistnych drzew

Nasze domy. Nasze północne miasta, ich ciężkie zegary wiszące na wieżach jak dynie w jesiennych ogrodach Nasze szpitale w ponurych gmachach, nasze sądy, mroczne urzędy pocztowe $\mathrm{z}$ czerwonej cegły

i strażacy w srebrzystych hełmach Nasze nieme ulice które wciąż czekają Północne miasta są introwertykami Wydają się potężne, niezniszczalne lecz naprawdę są dosyć nieśmiałe Rodzimy się w nich i umieramy Lubimy wypalone krajobrazy południa, ciemnogranatowe morze porysowane białymi wstążkami fal, brązowe skały, tamaryszek i figowiec pachnący słodkimi owocami, ale przykuto nas do północnych miast, i nie możemy ich zdradzić, nie wolno nam porzucić naszych ciemnych miast, ich długiej zimy, brudnej bielizny topniejącego śniegu, wstydu, smutku, zmęczenia Musimy mówić w ich imieniu, musimy czuwać, wołać

- wiersz ten nie zachwyca, a zawstydza.

W ramach komentarza można jedynie powtórzyć wcześniejsze uwagi (poziom obserwacji, jej zdystansowania, językowy wyraz) dotyczące charakteru wersów Zagajewskiego. 
Mogłabym jeszcze przywołać na przykład wiersz Nokturn i kilka innych jako zbliżone przykłady; w jednym z tekstów poetyckich (s. 74) wychwytuję metaforę „Atlantyk wieczności”. Już nie mówię o Peiperze, myślę, że Skamandryci i inni „klasycyzujący” byliby nieco zawstydzeni takimi wynalazkami. Każdy fragment twórczości, jakiejkolwiek twórczości, nawet jeśli poecie się nie uda, zdradza horyzonty autora, informuje o ogólnej jakości artystycznej i estetycznej konkretnego pisarstwa.

Jest we wspominanym tomie Zagajewskiego (i wielu innych jego książkach) trochę wierszy interesujących, jak wyraziłam się wcześniej - na równym poziomie - ale nie otwierają one żadnych drzwi, nie wskazują nieprzeczuwanych światów. Adam Zagajewski jest co najwyżej poetą średnim.

Przypadek zupełnie odmienny - Marcin Świetlicki.

Poeta inteligentny, poeta pewny siebie, traktujący język z góry; oczywiście ma do tego prawo; to prawo zostaje często przez Świetlickiego, pośrednio naturalnie, uzasadniane, dokumentowane. Świadomie i z niezwykłą starannością wykreował siebie na jedną z najważniejszych postaci poezji współczesnej. Krytyka literacka dość szybko dała się wmanewrować w ten proces, zaaranżowany przez samego Świetlickiego.

Biorę tomik Czynny do odwołania z 2001 roku (Wydawnictwo Czarne), wiersz Zabijanie (s. 50), też nie wyszukując specjalnie:

Przyjdziesz i zabijesz.

Przyjdziesz i zabijesz.

Jeszcze o tym nie wiesz.

Jeszcze nie rozumiesz.

Jeszcze stoisz w cieniu.

Jeszcze stoisz w tłumie,

ale

przyjdziesz i zabijesz.

Przyjdziesz i zabijesz.

(co się gnoju patrzysz?

czegoś nie rozumiesz? 
przyjdziesz i zabijesz,

tylko tyle umiesz,

po to tutaj jesteś,

po to się urodziłeś,

po to tutaj jesteś,

żeby mi się przyjrzeć)

Przyjdziesz i zabijesz.

Bo tyle zrozumiesz,

co zabijesz.

Mocna ekspresja, jasny, powiedziałabym, chociaż to nie wyczerpuje wiersza - moralistyczny przekaz. Zwarta, jednoznaczna formuła całości. Ale nie prowadzi mnie - czytelnika - daleko; zatrzymuje na pesymizmie obserwacji, w sytuacji odczytania reguł pewnej rzeczywistości.

Albo wiersz Zdradzanie (s. 51):

Czy nadal mieszkasz, gdzie mieszkałeś?

Czy nadal robisz tam, gdzie robiłeś?

- oto pytania, które mi zadają

najczęściej, gdy rozmowa mrze i

nie wiadomo już o co pytać.

A tak powinna brzmieć kompletna

moja odpowiedź: Otóż wszystko

uległo absolutnej zmianie.

Ja nadal mieszkam tam, gdzie mieszkałem.

Ja nadal robię tam, gdzie pracowałem.

Lecz w to nie wierzę.

Coraz bardziej.

Subtelne wychwycenie tego, co wyraźnie odsłonił już Rilke w Maltem, w znanym fragmencie o pisaniu listów. Prawda zawierająca się w elementarnym doświadczaniu czasu. Znów skupione, nieroniące słów, inteligentne wygranie struktury wiersza, ale również - znów nie prowadzi mnie, czytelnika, tak daleko, jak oczekuję (jako czytelnik poezji). Znajduję w tym tomie kilka bardzo dobrych, może świetnych, miniatur, na przykład Wracanie (s. 48): 
Późno i wszystko po nic. Wszystko po nic, na nic.

Wrócić, rzucić się, zasnąć. Nie przesadzać, nie śnić.

Wracam. Ale nie przyjdę do siebie tak łatwo.

Jeszcze trochę pochodzę

od małpy.

Albo wiele wierszy w rodzaju Dnienia (s. 16):

Rozwidniam. Widzę. Jestem

na dnie. I nie jest ładnie.

Jawnie i dennie jest mi.

Dnieje. Widzę dokładniej.

A nieboskłonem odwrócone dno.

Jakby unosiła Świetlickiego ta władza nad językiem i już - w tym momencie - uważna obserwacja świata wewnętrznego. Wiersze świetnie „rozegrane”, z „pazurem”, odległe od pozorów banalności, pozostawiają pewien czytelniczy niedosyt. Jeśli posłużymy się aksjologicznymi kryteriami Władysława Stróżewskiego (poczucie konieczności, absolutna afirmacja, skierowanie czytelnika poza tekst w przestrzeń wyższego rzędu $^{7}$ ), okaże się, że spełniony został warunek pierwszy. Świetlicki doskonale panuje nad słowem, w zasadzie żadnego $\mathrm{z}$ nich, w wierszach przywołanych, nie da się podmienić. Wydaje się, że mocno na tym poecie zaważyła postawa kontestacji; ale bunt już dawno przestał decydować o wartości w sztukach, a rewizjonizm rzadko współgra z naturą poezji. W oczywisty też sposób twórczość Świetlickiego ewoluuje, poetycko „owocne” porozumienie z czytelnikiem zdaje się wzrastać. W dalszym ciągu jednak czytelnik (czyli ja), rozumiejąc chyba niuanse języka i wtajemniczeń podmiotu tej poezji, nie potrafi dokonać pełnego „aktu afirmacji”, nie widzi również możliwości wyprowadzenia przez tę poezję tam, „gdzie ludzie nigdy nie bywali”.

Ze społecznie, medialnie, „kanonowo” ustalonych wielkości nie widzę ich potwierdzenia w wydawanych tomikach takich autorów jak - przykro mi to mówić w chwili obecnej - krótko po jego

7 Władysław Stróżewski, O pięknie, w: tegoż, Wokół piękna. Szkice z estetyki, Kraków 2002, s. 164-169. 
śmierci - Stanisław Barańczak, który po 1989 roku wydał osiem tomów poetyckich; skądinąd autor tak bardzo zasłużony dla kultury polskiej. Jako poeta - jakby nie rozumiał, nie czuł wielowymiarowości języka poetyckiego, nawet jego tłumaczenia jakby pozostawały bliżej translacji filologicznej niż artystycznej. Z pokolenia młodszego pomyłką wydaje się zbyt mocno wylansowana przez media prawicowe postać Wojciecha Wencla. Najogólniej: zwraca uwagę w tej twórczości pewna nieporadność językowa, nadmiar słów zużytych (mówię o słowach, nie wartościach, które są mi bliskie) - skłonność do mało wyrafinowanych powtórek z języka przeszłości, budzi niedosyt sposób obrazowania i asocjacje zawarte w wierszach.

Piszę to z pewnym żalem, ponieważ ktoś, kto podejmuje tematy tak ważne dla społecznej świadomości, pretenduje do - powiem górnolotnie: prawdy świata, jest odpowiedzialny również za jakość słowa, poziom artystycznej werbalizacji problemów. Wybrzmienie prawdy zależy również - zwłaszcza w uchu tych, którzy jej nie znają - od sposobu artykulacji. Znakomitym, pozytywnym przykładem będzie tu oczywiście Przemysław Dakowicz.

Istnieją też poeci - tu sąd ogólny - wylansowani przez oficjalne media i prasę literacką na czołowych poetów współczesności, uwodzący wrażliwością i świeżością spojrzenia, jakością artystycznego wyrazu. I często te sprawności mają charakter w pewien sposób pozorny; prowadzą do momentu - w trakcie aktu percepcyjnego - który okazuje się ślepą uliczką. Kto przeszedł przez te wersy, wie, że za szlachetnością odczuć, poczuciem wolności, starannym doświadczaniem i notowaniem dnia codziennego przez pierwsze odruchy wrażliwości w zasadzie nic nie stoi; pusto, a pustkę przerabiamy od Becketta i innych autorów, którzy mimo że o pustce pisali, wiedzieli, że jest to dotkliwość ludzkiej, dwudziestowiecznej kondycji. Z tą pustką bywa poetom do twarzy, ta pustka wydaje się pozytywnym bohaterem ich twórczości. Najczęściej przeszkadza mi w niej nihilizm, udawanie szlachetności, która, bywa, że staje się cynizmem.

Na mapie współczesnej poezji polskiej ważne miejsce zajmuje Opole. Najciekawszym zjawiskiem z tamtego kręgu jest dla mnie Paweł Marcinkiewicz, poeta i tłumacz, ale też pracownik anglistyki 
w Uniwersytecie Opolskim. Autor nie tak dużej liczby tomów, pozostający w pewnym cieniu, nieprzykładający raczej wagi do kreacji swojego imienia w prasie i mediach. Poeta autentyczny, ważny, pierwszorzędny. Po roku 1989 wydaje tomy: Zawieram z toba przymierze (1993), Świat dla opornych (1997), Tivoli (2000), real,- (2004). Na charakterze jego twórczości zaważyły głównie kwestie osobowościowe - jeśli można to nazwać w ten sposób (poza wszystkim to sprawa bodaj najważniejsza w liryce) - i wykształcenie filologiczne; językowa świadomość, zasymilowanie tradycji literackiej, w tym polskiej, praca tłumacza poezji, umiejętność starannej obserwacji świata; wszystko to dało znakomity rezultat poetycki.

Cytuję kilka fragmentów; jako pierwszy, dość sytuacyjny, niezupełnie typowy dla Marcinkiewicza:

Przepycham się za nimi przez labirynt półek. Kiedy zatrzymują się przy stoisku z pieczywem, ja też się zatrzymuję. Ona bierze bochenek razowego chleba, on dwa rogale; ja nic nie biorę.

[...]

Podsłuchuję i przyglądam się ich odbiciom w szybie.

A gdybym nagle zgasił światło i zapalił horyzont? Gdybym rozpiął na niebie łunę i wypełnił powietrze opętańczym wyciem, pióropuszem dymu? Kto kogo by stratował, zrzucił ze schodów, zmiażdżył, udusił?

[...]

[...] Ile miłości i przyjaźni skończyłoby się wyścigiem między półkami do drzwi, do parkingu, i dalej, do autostrady?

(Keymart. Apokalipsa, z tomu Świat dla opornych) 
Albo fragment Pamięci Josifa Brodskiego (z tomu Świat dla opornych):

I nikomu nie przyszło do głowy,

Aby zatrzymać zegary, odciąć telefony,

Wylać oceany, schować księżyc

Rozmontować słońce, bo nie będą już potrzebne.

(w. 22-25)

Gdzie indziej powtórka z Miłosza. Właśnie - p o w tó r k a - bo Marcinkiewicz nie naśladuje, nie - pożycza, nie - ulega wpływowi:

Kończy się pycha rytmicznej mowy. Cała ta wyprawa

Po złote runo formy zmieści się niedługo

Na niedużym kawałku krzemu. Przetrwa może

Jakaś notatka w jednotomowej encyklopedii,

Kilka zdjęć, anegdot, niektóre daty.

Okazało się, że nasz język jest jak pancerz u gadów

Czy ogon u człekokształtnych małp.

Uczynił nas władcami widzialnego świata,

A teraz, niepotrzebny, zanika i powracamy

Nad rzekę krzyku, do magicznej doliny obrazów.

Bądźcie wyrozumiałe, word-processory, dla poety,

Któremu słowa były konieczne jak miłość.

(w. 34-45)

I jeszcze fragment z tomu Tivoli (wiersz Królowo dni):

Pod blokiem sprzątaczka podzwania wiadrami

Jej rumiany kark bucha parą na mrozie.

Jestem królową waszych chudych dni,

gasnących jak nożem uciął, cierpkich i daremnych.

(w. 5-8)

Oto - gdzie indziej - widok z okna na fragment blokowiska:

Minęło czyjeś życie, a widok dalej trwa -

jest może nawet bardziej widokowy.

nie straszne mu mroczki ani krwawe pręgi.

Do wielkiej płyty mu bez tych rogowych okularów. 
Jakby go ożywiało coś więcej niż wzrok.

Jakby go uskrzydlały postępy nicości.

(Widok, w. 10-15)

Widzimy w tych wierszach przede wszystkim, jak znakomicie, subtelnie, przy użyciu minimalnych środków, a przede wszystkim przy wykorzystaniu literalnej obserwacji, wyrażone zostają: ograniczoność ludzkiego życia, przemijanie, przeczucie wieczności (?). Bez hałasu i niecierpliwego grzmocenia zdartymi do bólu słowami, co zdarza się poetom opatrzonym etykietą „metafizycznych” i wszelką inną górnolotnością.

Paweł Marcinkiewicz posługuje się pozornie prostą, czytelną metaforą, opowiada świat z uchwytną liryczną logiką. Często wykorzystuje najwłaściwszy chyba dla liryki elegijny sposób rysowania czasu ${ }^{8}$. Jeśli zdarzy mu się nostalgia - mocno zdystansowana - staje się (ta nostalgia) uczuciem konstruktywnym, wydobywającym coś ważnego.

Paweł Marcinkiewicz nie bywa banalny. Nie pozwala mu na to świetne rzemiosło poetyckie, językowa wrażliwość, werbalnie kontrolowana emocja, umiejętność tworzenia nowego układu obrazów.

Potrafi snuć erudycyjnie zagęszczoną opowieść z własnego życia, prowadzić ironiczną i humorystyczną grę z sobą i otoczeniem. Wykorzystuje do tego kolokwializację, zabawę, prymitywizm.

Tych kilka tomów zasadniczo wzbogaciło obraz poezji polskiej po 1989 roku; zajęło tam - faktycznie - jedno z najważniejszych miejsc.

Na koniec - „starzy poeci”; nieżyjący już klasycy; filary całościowej panoramy ostatnich dwudziestu pięciu lat. Pierwszy, oczywisty, to Miłosz, ze swoimi ostatnimi tomami, poczynając od Dalszych okolic (1991) przez To, Wiersze ostatnie, w dalszym ciągu dystansujący wszystkich innych swoim precyzyjnym i pełnym najszlachetniejszej urody językiem, obejmującym najgłębsze zakamarki współczesnego, zdegradowanego umysłu.

\footnotetext{
8 Pisałam o tym problemie u Pawła Marcinkiewicza w: Jednak elegia (szkic do problemu), w tomie $Z$ estetyki nieskończoności..., dz.cyt., s. 109-120.
} 
Drugi filar - ks. Janusz Stanisław Pasierb - właściwie poza nurtem życia literackiego, idący zupełnie własnymi drogami, dysponujący krystalicznym zmysłem obserwacji świata i introspekcji, połączonym z niezwykłym talentem nazywania, ogromną kulturą języka i autentyczną perspektywą Chrystocentryczną.

W 1989 roku Pasierb wydaje Doświadczanie ziemi i później znakomite tomy: Ten i tamten brzeg (1993), Puste łąki (1993) i Butelkęlejdejska (1995). Serdecznie, acz krytycznie nastawiony do kolegów kapłanów piszących poezje. (Pamiętamy, Pasierb wspierając się na osądzie Jana Pawła II, mówi: „Poezja to wielka pani / rzadko bywa na plebanii”). Pierwszorzędny poeta polski - po prostu, za którym daleko, daleko, pojawiają się inni (nie uwzględniam tu ks. Twardowskiego, nie ma chyba takiej potrzeby). Pasierb w przypisie do tytułu przywołanego dwuwersu (Poezja kapłańska) pisze znamienne: „Jest tylko poezja albo jej nie ma”.

\section{Summary \\ On Polish Poetry after 1989 (deficiencies and 'surpluses'). An essay in literary criticism}

The article addresses selected issues about Polish poetry after 1989. The author distinguishes between the poetry of 'a literary movement' and the poetry fulfilling the criteria of a veritable work of art. She critically comments on the selected works by well-known authors who function as part of an unspoken canon; she portrays the poetry of Paweł Marcinkiewicz as one of the most attractive proposals coming from the younger generation, whereas from among the classics she picks texts by Czesław Miłosz and Janusz St. Pasierb.

Bernadetta Kuczera-Chachulska (Uniwerytet Kardynała Stefana Wyszyńskiego, Instytut Badań Literackich PAN - prof. zw. dr hab; autorka prac z zakresu romantyzmu i estetyki poezji (m.in. Norwida «przypowieść o pięknem» i inne szkice z pogranicza genologii i estetyki, 2008; Z estetyki nieskończoności. Szkice o polskiej poezji (nie tylko) XX wieku, 2012). 